\title{
Conversion of Mill Scale Waste into Valuable Products via Carbothermic Reduction
}

\author{
Mamdouh Eissa, Azza Ahmed, and Mohamed El-Fawkhry \\ Steel Technology Department (STD), Central Metallurgical R\&D Institute (CMRDI), P.O. Box 87, Helwan, Cairo 11421, Egypt
}

Correspondence should be addressed to Mohamed El-Fawkhry; abdrabu1979kamal@yahoo.com

Received 1 June 2015; Accepted 30 August 2015

Academic Editor: Brij Kumar Dhindaw

Copyright (C) 2015 Mamdouh Eissa et al. This is an open access article distributed under the Creative Commons Attribution License, which permits unrestricted use, distribution, and reproduction in any medium, provided the original work is properly cited.

Mill scale is one of waste materials which is produced as a result of hot rolling of steel in all steel companies. On the other hand, mill scale is considered a rich iron source with minimum impurities. This work aims at conversion of mill scale by adjusting smelting processes to produce different valuable products. The smelting processes were carried out using carbothermic reduction in a submerged arc furnace. Two carbonaceous reducing agents and different fluxing materials have been used to adapt optimum smelting process condition. A maximum iron recovery of $83 \%$ was obtained by using graphite compared with $76 \%$ obtained by using coke. Low sulphur content $(\leq 0.02 \mathrm{wt} \% \mathrm{~S})$ can be attained by using graphite as a reducing agent in amount that equals or exceeds the stoichiometric molar ratio. By using coke, the highest degree of desulfurization of $97.8 \%$ and much lower content of sulphur in the castable metal $(0.0028 \mathrm{wt} \% \mathrm{~S})$ were obtained by controlling the type and quantity of the flux. The results reveal that mill scale waste can be converted into valuable products such as high purity iron as alternative to Sorelmetal used in ductile iron production, low carbon steel, and free cutting steel.

\section{Introduction}

The management of wastes generated by hot metal and steel has become an important issue due to ever-tightening environment regulations. Furthermore, the depletion of iron ores necessitates extensive research work to reuse the secondary raw materials produced as a by-product in steel companies and considered as waste materials.

During hot rolling of steel, iron oxides form on the surface of the metal as scales. The scale is accumulated as waste material in all steel companies. In an integrated steel plant, portion of mill scale, the large size one, was recycled in sintering plants [1]. But a study on recycling mill scale of steel in the sintering process showed that the sinter productivity decreased with the increase in mill scale addition due to a decrease in sinter bed permeability [2].

In the past years, steelmakers used this mill scale as oxidizer in conventional electric arc furnace steelmaking process. However, the modern electric arc furnaces are equipped with oxygen lancing system to enhance melting and oxidation processes with higher efficiency than mill scale practice [3]. A small portion of mill scale has been used by cement plants. However, the mill scale does not uniformly blend with the other feed stock materials due to its higher density than any of the blend components and thus causes a greater variation in the blend of the kiln feed [4]. At the same time, the amount of mill scale used by cement plants, as a raw material in the manufacturing of clinker, is still rather little.

A study on laboratory scale was made to use mill scale waste to prepare iron powder. The authors used $\mathrm{CO}$ followed by $\mathrm{H}_{2}$ as a reducing gas. When the reduction was carried out by carbon monoxide the maximum iron content $(98.40 \mathrm{wt} \% \mathrm{Fe})$ in the iron powder was obtained at $1050^{\circ} \mathrm{C}$ for $180 \mathrm{~min}$. A reduction annealing under hydrogen makes it possible to decrease carbon and oxygen contents of the reduced iron powder up to acceptable values, 0.23 and $0.28 \%$, respectively [5]. A recent study was made of the reduction of mill scale to sponge iron using coke at different temperatures and times. Sponge iron was successfully produced for reuse in electric furnaces as part of the metallic charge or as a raw material in the production of iron-based powder metallurgy parts [6].

Unfortunately, no technology has been implemented, in mass, to recover and use such materials [7]. In some 
steel manufacturing companies, the bulk of mill scale waste was dumped in landfills and resulted in leaching of some percentages of heavy metals into soil and groundwater, thus threatening the environment. The continuous demand for more landfills and bad effect on the environment highlight the need for more effective methods of productive utilization of mill scale.

In this study, mill scale waste produced in steel companies was recycled to produce valuable products by suitable smelting process using submerged arc furnace and carbonaceous reducing agent. The reductant and fluxing materials were optimized to obtain different valuable products.

\section{Experimental}

Mill scales generated in the hot rolling step of steel produced by electric arc furnace, EAF, together with reducing agent and fluxing material were used as raw materials. Sieve analysis, chemical composition, and XRD examination of mill scale were carried out. Reducing agents (crushed coke and crushed broken graphite electrode waste) and fluxing materials $(\mathrm{CaO}$, $\mathrm{CaF}_{2}, \mathrm{CaSi}, \mathrm{Al}_{2} \mathrm{O}_{3}$, and $\mathrm{Na}_{2} \mathrm{CO}_{3}$ ) chemical compositions were determined. The chemical composition was determined using X-ray fluorescence, XRF (Philips PW 1410 X-ray spectrometer with PW 1390 channel control). Phase analysis was observed using X-ray diffractometer, XRD, Bruker AXS D8 Advance, Germany.

Different series of experimental runs were carried out using $5 \mathrm{~kg}$ of mill scale. The first and second series were carried out to investigate the effect of the type and the amount of reducing agent at constant weight $(500 \mathrm{gm})$ of calcium oxide and calcium fluoride with the weight ratio $4: 1$. The third series was designed to investigate the effect of different fluxing materials on decreasing the sulfur content of the castable metal by coke reduction.

The third series was subdivided into three subseries as follows:

(1) Fluxing material in the form of calcium oxide and calcium fluoride (weight ratio $4: 1$ ) was added in the furnace with the charge in increment amount from 0 to $750 \mathrm{gm}$.

(2) Fluxing material $(250 \mathrm{gm})$ in the form of calcium oxide and calcium fluoride (weight ratio $4: 1$ ) was added in the furnace with the charge and a mixture of $250 \mathrm{gm}$ of another type of the fluxing material was added in a metallic mold.

(3) Fluxing material (500 gm) in the form of calcium oxide and calcium fluoride (weight ratio $4: 1$ ) was added in the furnace with the charge and a mixture of $250 \mathrm{gm}$ of another fluxing material was added in a metallic mold.

Different fluxing materials were investigated: $\mathrm{CaSi}, \mathrm{Na}_{2} \mathrm{CO}_{3}$, $\mathrm{CaO}-\mathrm{CaF}_{2}-\mathrm{Al}_{2} \mathrm{O}_{3}$, and $\mathrm{CaO}-\mathrm{CaF}_{2}-\mathrm{FeSi}-\mathrm{C}$. The fluxing addition in the mold was carried out during tapping to enhance the contact area between slag and metal.

For each experimental run, the amount of the reducing agent required for $5 \mathrm{Kg}$ mill scale was calculated according to the material balance. In the third series, constant amount of coke was used (1.5 of the stoichiometric molar ratio).

The smelting experimental runs were carried out in a pilot plant submerged electric arc furnace. The furnace wall and bottom were rammed with a thick magnesite layer. For selecting the voltage and current suitable for carrying out smooth melting of the charge, preliminary experiments were carried out. It was found that the best current for melting the charge has $480 \mathrm{~A}$ and $35 \mathrm{~V}$.

To carry out the experimental runs, the components of the charge, mill scale, reducing agent, and flux materials, were hand mix together. The furnace was preheated to about $1000^{\circ} \mathrm{C}$ for 30 minutes. After all of the main charge had been completely melted, the molten metal and slag were left for 30 minutes with the current switch on to ensure the maximum degree of reduction and complete settling of the molten metal into the slag. The maximum temperature achieved in the furnace was about $1700^{\circ} \mathrm{C}$. The product was cast into metallic moulds where the metal covered by the slag was left to cool to room temperature. The castable metal of every experimental run was weighed and representative samples were then taken for chemical compositions using spectrographic analysis (Spectro Analytical Instruments).

\section{Result and Discussion}

During this investigation, different parameters affect the reduction of mill scale and quality of castable metal was studied. These parameters include the type and amount of reducing agent, the type and amount of fluxing material, and the technology of fluxing material addition. Two techniques of addition were investigated. In the first one, all amount of fluxing material was added in the furnace. In the second technique, a portion of fluxing material was added in the furnace while another portion was added in the mold during tapping.

The sieve analysis of mill scale is given in Table 1 , and its chemical composition is shown in Table 2. It is clear from Table 2 that the mill scale contains mainly iron oxides and a small amount of $\mathrm{SiO}_{2}$ and $\mathrm{MnO}$. The other oxides are present in minor amounts. At the same time the results of XRD examination of mill scale showed the presence of iron in the form of hematite $\left(\mathrm{Fe}_{2} \mathrm{O}_{3}\right)$, magnetite $\left(\mathrm{Fe}_{3} \mathrm{O}_{4}\right)$, and wustite $(\mathrm{FeO})$, Figure 1 . The reductants (coke and graphite) chemical compositions are given in Table 3 . In addition, the chemical composition of coke ash is given in Table 4 .

\section{Effect of the Reducing Agent}

Coke or graphite was used as a reducing agent. The amount of reducing agent was increased from 0.7 up to 1.7 from the calculated stoichiometric molar value. Stoichiometric molar ratios of $\mathrm{C} / \mathrm{O}$ higher than 1 were used to compensate the carbon consumed in reducing of reducible oxides such as $\mathrm{MnO}$ and $\mathrm{SiO}_{2}$. Figure 2 shows the effect of carbon stoichiometric molar ratio (C-S.R) on iron recovery. From the figure, the iron recovery increases as the amount of reductant increases up to about 1.5 of stoichiometric molar ratio. This result agrees with the result of Camci et al. [1]. 
TABLE 1: Sieves analysis of EAF mill scale.

\begin{tabular}{lccccccccc}
\hline $\begin{array}{l}\text { Volume fraction } \\
(\mathrm{mm})\end{array}$ & -0.1 & +0.1 & +0.25 & +0.5 & +1 & +2 & +3 & +4 & +4.7 \\
\hline $\mathrm{Wt} \%$ & 4.1 & 14.8 & 19.0 & 7.8 & 20.8 & 1.0 & 20.7 & 3.8 & 8.0 \\
\hline
\end{tabular}

TABLE 2: Chemical compositions, wt $\%$, of EAF mill scale.

\begin{tabular}{ccccccccccccccc}
\hline $\mathrm{Fe}_{\text {Total }}$ & $\mathrm{Fe}_{2} \mathrm{O}_{3}$ & $\mathrm{SiO}_{2}$ & $\mathrm{Al}_{2} \mathrm{O}_{3}$ & $\mathrm{~K}_{2} \mathrm{O}$ & $\mathrm{CaO}$ & $\mathrm{MnO}$ & $\mathrm{TiO}_{2}$ & $\mathrm{MgO}$ & $\mathrm{Na}_{2} \mathrm{O}$ & $\mathrm{P}_{2} \mathrm{O}_{5}$ & $\mathrm{CuO}$ & $\mathrm{Cr}_{2} \mathrm{O}_{3}$ & $\mathrm{~S}$ & LOI \\
\hline 67.55 & 96.5 & 0.68 & 0.16 & 0.012 & 0.13 & 1.022 & 0.013 & 0.10 & 0.04 & 0.074 & 0.4 & 0.14 & 0.013 & 1.1 \\
\hline
\end{tabular}

TABLE 3: Reducing materials chemical compositions, wt\%.

\begin{tabular}{lccccc}
\hline & $\mathrm{C}_{\text {fixed }}$ & $\mathrm{S}$ & Ash & VM & Moisture \\
\hline Coke & 82.6 & 0.7 & 13.5 & 1.4 & 1.8 \\
Graphite & 99.5 & 0.1 & 0.4 & & \\
\hline
\end{tabular}

TABLE 4: Chemical compositions, wt\%, of coke ash.

\begin{tabular}{ccccccccc}
\hline $\mathrm{SiO}_{2}$ & $\mathrm{Al}_{2} \mathrm{O}_{3}$ & $\mathrm{Fe}_{2} \mathrm{O}_{3}$ & $\mathrm{CaO}$ & $\mathrm{MgO}$ & $\mathrm{MnO}$ & $\mathrm{TiO}_{2}$ & $\mathrm{~S}$ & $\mathrm{P}$ \\
\hline 46.2 & 32.85 & 15.4 & 3 & 0.25 & 0.65 & 1 & 0.12 & 0.028
\end{tabular}

Above this amount the increasing of the reductant amount leads to decrease of the iron recovery. This may be due to overreductant amount. The improper utilization of reductant can be understood in the light of the iron oxide reduction reactions. As indicated from XRD analysis the constituents of mill scale were $\mathrm{Fe}_{2} \mathrm{O}_{3}, \mathrm{Fe}_{3} \mathrm{O}_{4}$, and $\mathrm{FeO}$ phases. The possible reduction of these oxides is

$$
\begin{gathered}
\mathrm{Fe}_{m} \mathrm{O}_{n}+(n-m) \mathrm{CO} \longrightarrow m \mathrm{FeO}+(n-m) \mathrm{CO}_{2} \\
\mathrm{Fe}_{m} \mathrm{O}_{n}+n \mathrm{C} \longrightarrow m \mathrm{Fe}+n \mathrm{CO}
\end{gathered}
$$

Reaction (1) is called indirect reaction while reaction (2) is called direct reaction. When the temperature was $800-$ $1000^{\circ} \mathrm{C}$, the reaction at the surface of the reductant was suitable to make the mill scale reduction and the "Boudouard reaction" in (3) to run simultaneously. As a result, the $\mathrm{CO}_{2}$ gas formed by reduction of mill scale reacted with carbon to give the reaction:

$$
\begin{aligned}
\mathrm{C}+\mathrm{CO}_{2} \longrightarrow 2 \mathrm{CO} \\
\qquad G^{\circ}(\mathrm{J} / \text { mole })=148370.25-46.2737 \mathrm{~T}
\end{aligned}
$$

It seems that over-reductant amount encourages the "Boudouard reaction" to occur which retarded the direct reduction of mill scale, reaction (2).

Also, by comparing the maximum iron recovery, it can be noticed that the maximum iron recovery obtained when using coke (76\%) was lower than when using graphite (83\%). This can be attributed, besides the effect of over-reductant, to the ash constituents in the coke. According to the literature [5] the coke ash components such as silica, alumina, and silicates alter the reduction equilibrium.

The increase of the iron recovery was reflected on the weight of the castable metal. Thus, the weight of the castable metal increased with increasing the amount of the reductant.

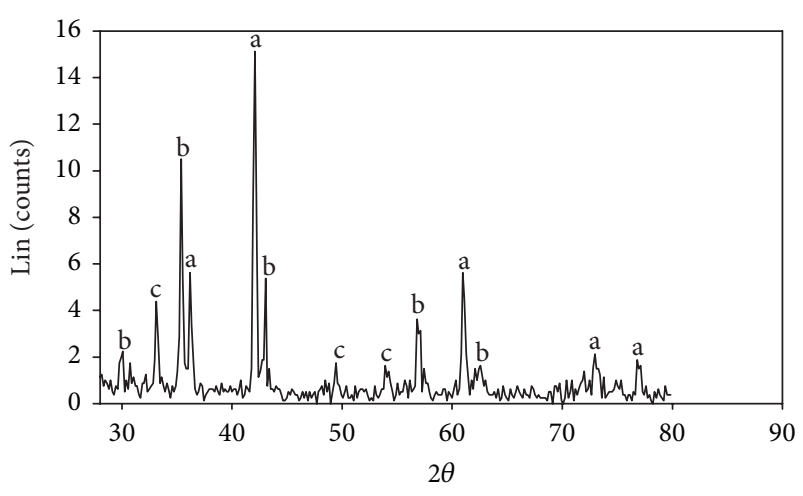

a: wustite

b: magnetite

c: hematite

FIGURE 1: XRD on mill scale of steel produced in EAF.

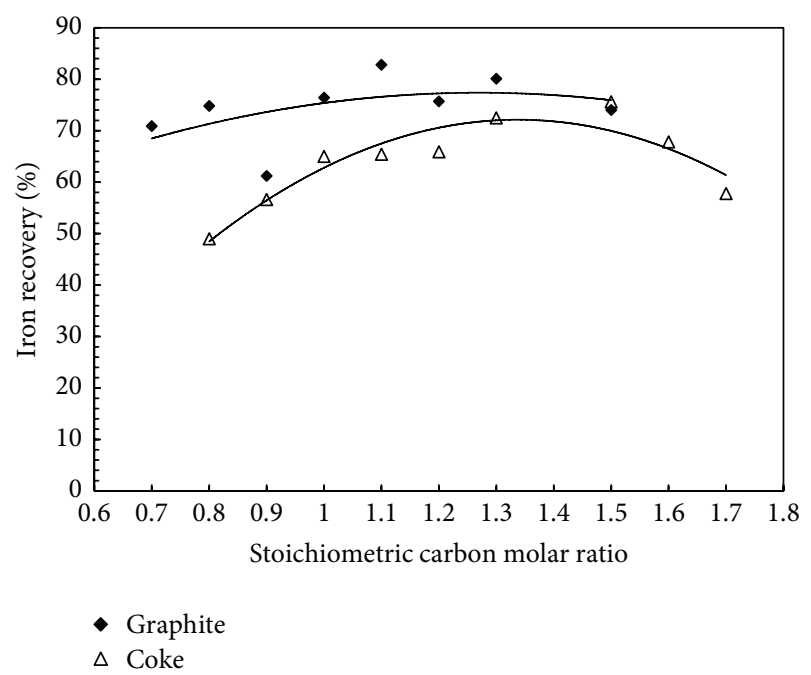

FIgURE 2: Influence of the amount of reducing agent on iron recovery.

The reductant type and amount do not only affect the metal weight and iron recovery but also affect the chemical composition of the castable metal. So, the relationship between the amount and type of the reductant with the weight chemical composition of the castable metal, C, S, P, Mn, and $\mathrm{Si}$, was studied. 


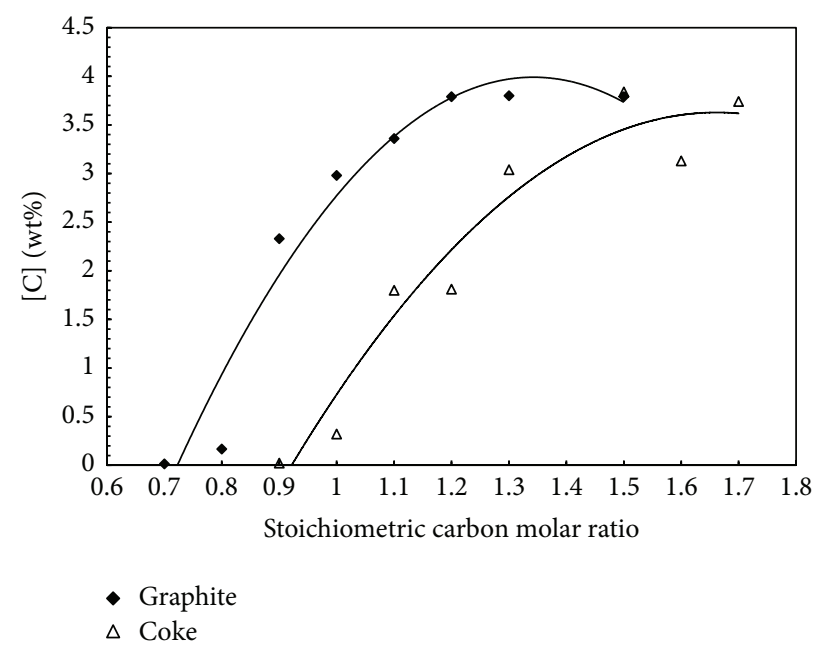

Figure 3: Influence of the amount of reducing agent on metal carbon content.

The change of final metal carbon content with the stoichiometric carbon molar ratio, at different reductant agents, can be revealed from Figure 3. The carbon content of the metal increases with increase of reductant amount. But after reaching a maximum value, the metal carbon content decreases. This behavior can be explained in the light of dissolution and removal of carbon from the iron. The carbon is dissolved into iron through the following reactions:

$$
\begin{aligned}
\mathrm{C}_{\mathrm{s}} & \longrightarrow \mathrm{C}_{\text {in metal }} \quad \Delta G^{\circ}(\mathrm{J} / \text { mole })=22594-4228 T \\
2 \mathrm{CO}_{\mathrm{g}} \longrightarrow \mathrm{C}_{\text {in metal }}+\mathrm{CO}_{2} & \\
& \Delta G^{\circ}(\mathrm{J} / \mathrm{mole})=-148370.25+46.2737 \mathrm{~T}
\end{aligned}
$$

while it can be removed from the iron through the following reactions:

$$
\begin{aligned}
& \mathrm{O}_{\text {in metal }}+\mathrm{C}_{\text {in metal }} \longrightarrow \mathrm{CO}_{\mathrm{g}} \\
& \Delta G^{\circ}(\mathrm{J} / \text { mole })=-18319-41.369 \mathrm{~T} \\
& \mathrm{CO}_{2}+\mathrm{C}_{\text {in metal }} \longrightarrow 2 \mathrm{CO}_{\mathrm{g}} \\
& \Delta G^{\circ}(\mathrm{J} / \mathrm{mole})=148370.25-46.2737 \mathrm{~T}
\end{aligned}
$$

At low stoichiometric carbon molar ratio up to 1.2 the reaction rate of the dissolution was faster than the rate of the removal and this trend increased by increasing stoichiometric carbon molar ratio. This results in increasing the final carbon content of the castable metal. On the other hand, decreasing the metal carbon content after reaching the maximum content resulted from increasing the reaction rate of the carbon (reactions (6)-(7)) especially that of Bodouard reaction, as it is discussed before. Furthermore, it is noticed that, at the same stoichiometric carbon molar ratio, the metal carbon content when using coke was less than metal carbon content when using graphite. This behavior could be attributed to the higher reactivity of the coke $\left(0.1-0.5 \times 10^{-4} \mathrm{~S}^{-1}\right)$ than that of the graphite $\left(0.03 \times 10^{-4} \mathrm{~S}^{-1}\right)$ [8], which means that the rates

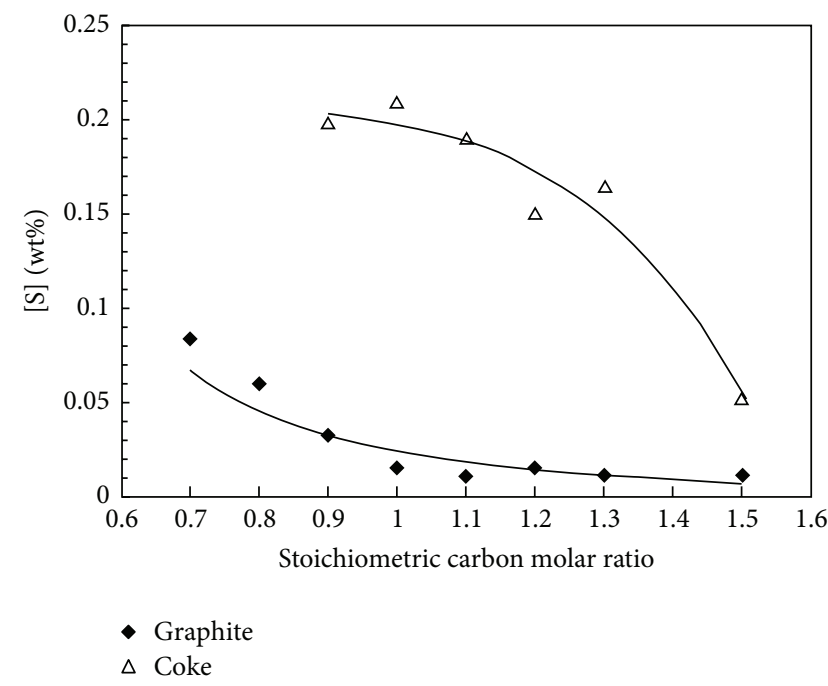

FIgURE 4: Influence of the amount of reducing agent on metal sulphur content.

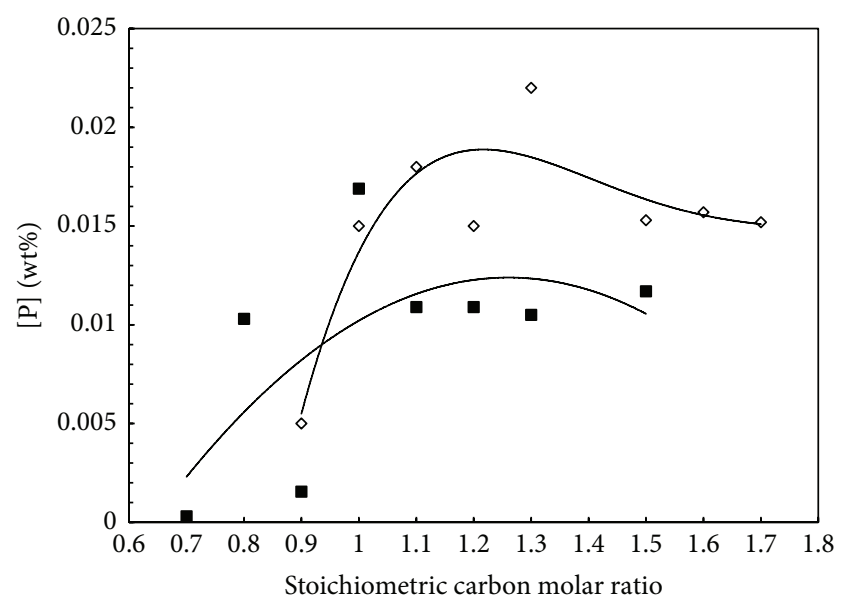

- Graphite

○ Coke

FigURE 5: Influence of the amount of reducing agent on metal phosphorous content.

of gasification reactions (6) and (7) are faster for coke than graphite.

The relationship between sulphur and phosphorous contents of the metal and stoichiometric carbon molar ratio is shown in Figures 4 and 5, respectively. It is clear from Figure 4 that the sulphur content of the metal decreases by increasing the reducing agent amount (graphite or coke). On the contrary, the phosphorus had the opposite behavior as it increased by increasing the amount of reducing agent, Figure 5.

The sulphur and phosphorous behavior could be explained in terms of slag condition. Dephosphorization and desulfurization of hot metal are known to proceed under different conditions. The most popular method of desulphurization is removal of sulphur from metal to the basic reducing 
slag, while the most popular dephosphorization is removal of phosphorous from metal to the basic oxidizing slag, as indicated from the following chemical equations [9-11]:

$$
[\mathrm{S}]+(\mathrm{CaO})=(\mathrm{CaS})+[\mathrm{O}]
$$

The equilibrium constant $K_{\mathrm{S}}$ of the reaction is

$$
K_{\mathrm{S}}=\frac{a_{[\mathrm{O}]} * a_{(\mathrm{CaS})}}{a_{[\mathrm{S}]} * a_{(\mathrm{CaO})}},
$$

where $a_{[\mathrm{O}]}$ and $a_{[\mathrm{S}]}$ are activities of oxygen and sulphur in the liquid metal; $a_{(\mathrm{CaS})}$ and $a_{(\mathrm{CaO})}$ are activities of $\mathrm{CaS}$ and $\mathrm{CaO}$ in the slag:

$$
2[\mathrm{P}]+5(\mathrm{FeO})+3(\mathrm{CaO})=\left(3 \mathrm{CaO} \cdot \mathrm{P}_{2} \mathrm{O}_{5}\right)+5 \mathrm{Fe}
$$

The equilibrium constant $K_{\mathrm{P}}$ of the reaction is

$$
K_{\mathrm{P}}=\frac{a_{\left(3 \mathrm{CaO} \cdot \mathrm{P}_{2} \mathrm{O}_{5}\right)}}{\left.a_{[\mathrm{P}]}^{2} * a_{(\mathrm{CaO})}\right)^{3} * a_{(\mathrm{FeO})}{ }^{5}},
$$

where $a_{[\mathrm{P}]}$ is activity of phosphorus in the liquid metal; $a_{\left(3 \mathrm{CaO} \cdot \mathrm{P}_{2} \mathrm{O}_{5}\right)}, a_{(\mathrm{CaO})}$, and $a_{(\mathrm{FeO})}$ are activities of $\left(3 \mathrm{CaO} \cdot \mathrm{P}_{2} \mathrm{O}_{5}\right)$, $\mathrm{CaO}$, and $\mathrm{FeO}$ in the slag.

These series of experiments have nearly constant slag basicity because constant weight of fluxing material was added. So, the behavior of sulphur and phosphorus at different reducing agent was related to the effect of the slag iron oxide content. Increase of the reducing agent amount leads to decreasing slag iron oxide content and increasing metal carbon content. The activity of the oxygen in the melt is directly proportional to the slag iron oxide content [12]. Therefore, low activity of oxygen in the metal is expected leading to appropriate conditions for the removal of the sulphur and desulphurization of the metal, as it is indicated from (8). On the contrary, these conditions encourage rephosphorization process and consequently the phosphorus content in the metal increases as the reducing agent increases, as it is indicated from (11).

On the other hand, the metal sulphur and phosphorous content produced when using graphite is less than coke at the same stoichiometric carbon molar ratio. This could be attributed to the lower sulphur and phosphorous contents of graphite compared with coke.

Also, it can be observed that, at different type and amount of the reductant, the metal phosphorous content is low and in the range of the iron and steel making. Therefore, the phosphorous content of the castable metal does not represent any problem.

Figure 6 illustrates the relationship between the amount of the reductant and the silicon and manganese contents of the metal. As expected, both the silicon and manganese contents of the castable metal increase with increasing amount of the reductant. The coke ash contains $\mathrm{SiO}_{2}$ and $\mathrm{MnO}$. At the same stoichiometric carbon it is expected that the silicon and manganese contents of the metal produced by coke reduction are higher than that obtained by graphite reduction. But the results showed the opposite behavior to the expected one. This result can be explained in the light of the effect of the

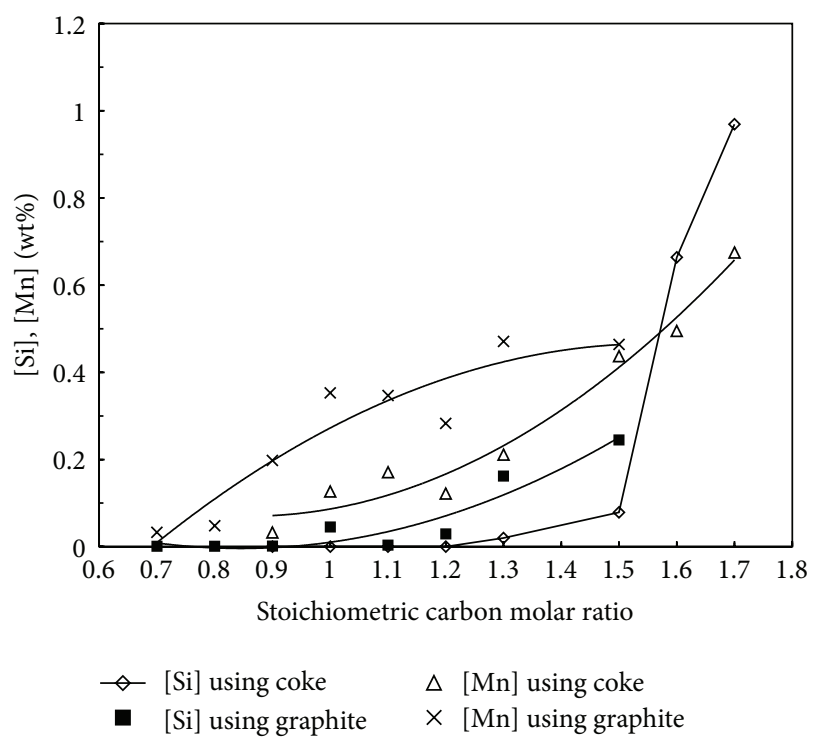

FIGURE 6: Influence of the amount of reducing agent on $\mathrm{Mn}$ and $\mathrm{Si}$ content of the metal.

slag $\mathrm{FeO}$ content on the reduction of the manganese and silicon oxides. As it is revealed in Figure 2 the iron recovery obtained when using graphite was greater than that obtained by coke. This indicates that the $\mathrm{FeO}$ content of the slag when using graphite is less than that obtained when using coke. The reduction of the oxides increases with decreasing $\mathrm{FeO}$ content of the slag; subsequently, the transfer of the silicon and manganese to the metal increases.

Also, the sharp increase in the silicon content after 1.5 of stoichiometric carbon molar ratio can be noticed. This trend results from the fact that the reducing ability of $\mathrm{SiO}_{2}$ by carbon is less than that of $\mathrm{MnO}$, as it is indicated from free energy of reactions (12) and (13):

$$
\begin{gathered}
\left(\mathrm{SiO}_{2}\right)+2[\mathrm{C}]=[\mathrm{Si}]+2 \mathrm{CO} \\
\Delta G^{\circ}(\mathrm{J} / \text { mole })=611302-336.47 \mathrm{~T} \\
(\mathrm{MnO})+[\mathrm{C}]=[\mathrm{Mn}]+\mathrm{CO} \\
\Delta G^{\circ}(\mathrm{J} / \text { mole })=219521-146.68 \mathrm{~T}
\end{gathered}
$$

Thus, when most of $\mathrm{MnO}$ was reduced, the reduction rate of $\mathrm{SiO}_{2}$ increases leading to sharp increase of the metal silicon content.

Variations of chemical composition of castable metal with coke and graphite at different amounts of the reductant are given in Tables 5 and 6 , respectively. These results show that valuable products can be achieved by controlling the type and amount of the reductant such as

(1) low carbon steel containing $0.17 \mathrm{wt} \% \mathrm{C}, 0.05 \mathrm{wt} \% \mathrm{~S}$, and $0.01 \mathrm{wt} \% \mathrm{P}$ (steel number 10),

(2) low carbon high sulphur steel which can be used as free cutting steel by adding the adjusting $\mathrm{Mn}$ at tapping (steel numbers 1 and 2), 


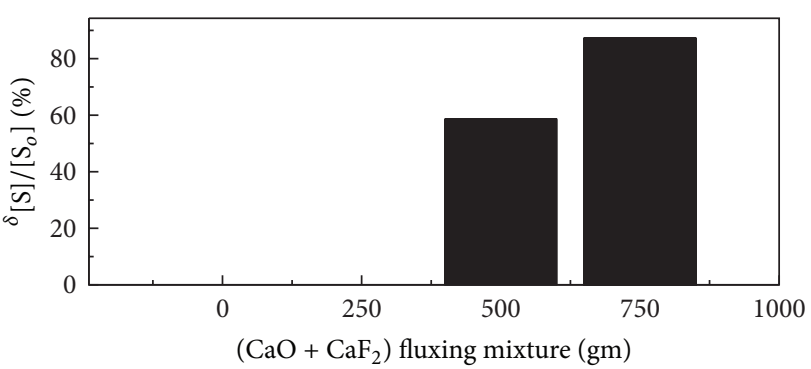

(a)

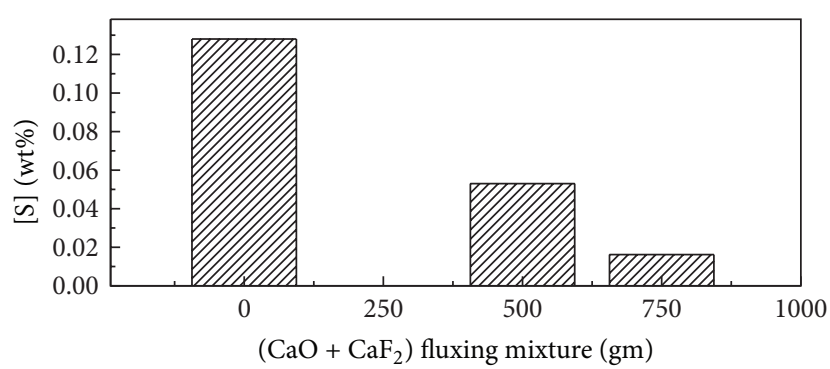

(b)

Figure 7: Variation of sulphur content and desulfurization degree of the metal with respect to $\mathrm{CaO}-\mathrm{CaF}_{2}$ fluxing mixture amount added in the furnace.

TABLE 5: Mill scale experimental runs (reducing agent: coke).

\begin{tabular}{lccccc}
\hline \multirow{2}{*}{ Heat number } & \multicolumn{3}{c}{ Stoichiometric carbon } & \multicolumn{3}{c}{ Chemical composition of produced metal, wt\% } \\
& & $\mathrm{C}$ & $\mathrm{Si}$ & $\mathrm{Mn}$ & $\mathrm{S}$ \\
\hline 1 & 0.9 & 0.02 & 0.001 & 0.032 & 0.199 \\
2 & 1.0 & 0.32 & 0.004 & 0.127 & 0.210 \\
3 & 1.1 & 1.80 & 0.005 & 0.171 & 0.191 \\
4 & 1.2 & 1.81 & 0.008 & 0.122 & 0.151 \\
5 & 1.3 & 3.04 & 0.020 & 0.211 & 0.015 \\
6 & 1.5 & 3.84 & 0.079 & 0.337 & 0.015 \\
7 & 1.6 & 3.13 & 0.664 & 0.495 & 0.053 \\
8 & 1.7 & 3.74 & 0.969 & 0.675 & 0.067 \\
\hline
\end{tabular}

(3) high purity high carbon iron with chemical composition (3.8 wt $\%$ C, $0.28 w t \% \mathrm{Mn}, 0.015 \mathrm{wt} \% \mathrm{~S}$, and $0.01 \mathrm{wt} \% \mathrm{P}$ ) suitable as an alternative of Sorelmetal to be used for the ductile iron production (steel number 14),

(4) iron high carbon (3.8wt.\%) and low phosphorus (0.015 wt.\%) but containing high sulphur (0.053 wt.\%) (steel number 6): it can be used as an alternative of Sorelmetal after reducing the sulfur content by using suitable fluxing agent with higher desulphurizing power.

\section{Effect of Fluxing Materials}

The preceding results demonstrate the success of the carbothermic reduction for mill scale by either coke or graphite in producing different grades of iron and steel with low phosphorus contents $(\leq 0.02 \mathrm{wt} \% \mathrm{P})$. Low-sulphur content $(<0.02 \mathrm{wt} \% \mathrm{~S})$ can be also attained by using graphite as a reducing agent in amount that equals or exceeds the stoichiometric molar ratio. On the other hand, metal with higher sulphur content was produced when using coke as reducing agent. Producing low-sulphur metal $(\leq 0.02 \mathrm{wt} \% \mathrm{~S})$ necessitates using higher amount of coke that equals or exceeds 1.7 of stoichiometric molar ratio.

Different technologies and fluxing materials were used to decrease the sulphur content in castable metal from mill scale reduced by coke. To investigate the fluxing materials effect, the third series of experiments was carried out. Two techniques of addition were investigated. In the first one, all amount of fluxing material was added in the furnace. In the second technique, a portion of fluxing material was added in the furnace while another portion was added in the mold during tapping. The variations of fluxing materials for this series and the chemical composition of the castable metals are given in Table 7 .

The achieved results of subseries 3.1 of the third series are plotted in Figure 7, where the variation of sulphur content of the metal and desulphurization degree are plotted with respect to the variation of the quantity of a mixture of $\mathrm{CaO}$ and $\mathrm{CaF}_{2}$ (weight ratio $4: 1$ ). The desulphurization degree was calculated as follows:

$$
\frac{{ }^{\delta}[\mathrm{S}]}{\left[\mathrm{S}_{o}\right]}=\frac{\left(\left[\mathrm{S}_{o}\right]-\left[\mathrm{S}_{i}\right]\right)}{\left[\mathrm{S}_{o}\right]},
$$

where $\left[\mathrm{S}_{i}\right]$ is sulphur content of castable metal in run $i$ and $\left[\mathrm{S}_{o}\right]$ is sulphur content of castable metal in reference run (without fluxing addition).

In the reference run, without flux addition, the sulphur content of the castable metal was high $(0.128 \mathrm{wt} \% \mathrm{~S})$. Desulphurization degree of $58.6 \%$ was attained by adding $500 \mathrm{gm}$ of $\mathrm{CaO}$ and $\mathrm{CaF}_{2}$ mixture with charge in the furnace, but the sulphur content of the castable metal was still considerably high (0.053 wt $\% \mathrm{~S})$. However, higher desulphurization degree of $87.3 \%$ was attained when adding $750 \mathrm{gm}$ of $\mathrm{CaO}$ and $\mathrm{CaF}_{2}$ mixture resulting in a decrease of the sulphur content of the metal to be $0.0162 \mathrm{wt} \%$. 
TABLE 6: Mill scale experimental runs (reducing agent: graphite).

\begin{tabular}{lcccccc}
\hline \multirow{2}{*}{ Heat number } & \multirow{2}{*}{ Stoichiometric carbon } & \multicolumn{3}{c}{ Chemical composition of produced metal, wt\% } \\
\hline 9 & & $\mathrm{C}$ & $\mathrm{Si}$ & $\mathrm{Mn}$ & $\mathrm{S}$ & 0.0835 \\
10 & 0.7 & 0.014 & 0.0009 & 0.033 & 0.0003 \\
11 & 0.8 & 0.167 & 0.0009 & 0.048 & 0.0498 & 0.0103 \\
12 & 0.9 & 2.33 & 0.0015 & 0.198 & 0.0322 & 0.0015 \\
13 & 1.0 & 2.98 & 0.0454 & 0.353 & 0.0143 \\
14 & 1.1 & 3.36 & 0.0038 & 0.347 & 0.0100 & 0.0169 \\
15 & 1.2 & 3.79 & 0.0294 & 0.283 & 0.0151 \\
16 & 1.3 & 3.80 & 0.1620 & 0.471 & 0.0109 \\
\hline
\end{tabular}

TABLE 7: Experimental series according to variation of the flux materials and chemical composition of the castable metal (using coke as reducing agent).

\begin{tabular}{|c|c|c|c|c|c|c|c|}
\hline \multirow{2}{*}{ Series } & \multicolumn{2}{|c|}{ Fluxing materials, gm } & \multicolumn{5}{|c|}{ Chemical analysis of produced metal, wt $\%$} \\
\hline & With charge $(\mathrm{CaO})-\left(\mathrm{CaF}_{2}\right)$ & In mould & $\mathrm{C}$ & $\mathrm{Si}$ & $\mathrm{Mn}$ & S & $\mathrm{P}$ \\
\hline \multirow{3}{*}{3.1} & - & - & 3.46 & 0.356 & 0.217 & 0.128 & 0.0241 \\
\hline & $(400)-(100)$ & - & 3.84 & 0.079 & 0.437 & 0.053 & 0.0153 \\
\hline & $(600)-(150)$ & - & 3.65 & 0.725 & 0.649 & 0.0162 & 0.0216 \\
\hline \multirow{5}{*}{3.2} & $(200)-(50)$ & $\begin{array}{l}(\mathrm{CaO})-\left(\mathrm{CaF}_{2}\right) \\
(200)-(50) \\
(80 \%)-(20 \%)\end{array}$ & 3.37 & 0.300 & 0.26 & 0.118 & 0.0181 \\
\hline & $(200)-(50)$ & $\begin{array}{c}(\mathrm{CaSi}) \\
(250)\end{array}$ & 3.49 & 1.11 & 0.549 & 0.060 & 0.0211 \\
\hline & $(200)-(50)$ & $\begin{array}{c}(\mathrm{CaO})-\left(\mathrm{CaF}_{2}\right)-(\mathrm{FeSi})-(\mathrm{C}) \\
(157)-(31)-(31)-(31) \\
(62.5 \%)-(12.5 \%)-(12.5 \%)-(12.5 \%)\end{array}$ & 3.42 & 0.679 & 0.57 & 0.085 & 0.0185 \\
\hline & $(200)-(50)$ & $\begin{array}{c}(\mathrm{CaO})-\left(\mathrm{CaF}_{2}\right)-\left(\mathrm{Al}_{2} \mathrm{O}_{3}\right) \\
(38)-(137)-(75) \\
(15 \%)-(55 \%)-(30 \%)\end{array}$ & 3.66 & 0.502 & 0.524 & 0.103 & 0.0234 \\
\hline & $(200)-(50)$ & $\begin{array}{c}\left(\mathrm{Na}_{2} \mathrm{CO}_{3}\right) \\
(250)\end{array}$ & 3.59 & 0.601 & 0.493 & 0.109 & 0.0238 \\
\hline \multirow{3}{*}{3.3} & (400)-(100) & $\begin{array}{l}(\mathrm{CaO})-\left(\mathrm{CaF}_{2}\right) \\
(200)-(50) \\
(80 \%)-(20 \%)\end{array}$ & 3.62 & 0.855 & 0.604 & 0.0107 & 0.0229 \\
\hline & $(400)-(100)$ & $\begin{array}{l}(\mathrm{CaSi}) \\
(250)\end{array}$ & 3.61 & 1.92 & 0.60 & 0.0028 & 0.0199 \\
\hline & $(400)-(100)$ & $\begin{array}{c}(\mathrm{CaO})-\left(\mathrm{CaF}_{2}\right)-(\mathrm{FeSi})-(\mathrm{C}) \\
(157)-(31)-(31)-(31) \\
(62.5 \%)-(12.5 \%)-(12.5 \%)-(12.5 \%)\end{array}$ & 3.59 & 0.973 & 0.650 & 0.0174 & 0.0241 \\
\hline
\end{tabular}

The results of subseries 3.2 are presented in Figure 8, where the variation of sulphur content of the metal and desulphurization degree are plotted versus the different fluxing materials. It was clear that $\mathrm{CaSi}$ was the most effective desulphurized agent among the different fluxing materials used in this investigation. However, the highest desulphurization degree was only $53.1 \%$ and sulphur content of the castable metal was still considerably high $(0.060 \% \mathrm{~S})$.

On the other hand, Figure 9 illustrates that increasing the amount of $\mathrm{CaO}-\mathrm{CaF}_{2}$ mixture (weight ratio $4: 1$ ) in the furnace to $500 \mathrm{gm}$ and adding another $250 \mathrm{gm}$ of this mixture in the mold gives higher degree of desulfurization of $91.6 \%$ and lower content of sulphur in the metal $(0.0107 \mathrm{wt} \% \mathrm{~S})$.
Much higher degree of desulfurization of $97.8 \%$ and much lower content of sulphur in the castable metal (0.0028 wt-\%) were obtained when adding $250 \mathrm{gm}$ of $\mathrm{CaSi}$ in the mold instead of $\mathrm{CaO}-\mathrm{CaF}_{2}$ mixture.

The effect of the type and amount of the flux on the metal sulfur content could be attributed to its effect on the slag basicity. Figure 10 illustrates the relation between the metal sulphur content and slag basicity. It was clear from this figure that the metal sulphur content decreases by increasing the slag basicity. It can be also noticed that, at the same slag basicity, the dotted line (fluxing material includes $\mathrm{CaSi}$ ) represents lower sulphur content comparing to the solid line (fluxing material does not include $\mathrm{CaSi}$ ). This behavior could 


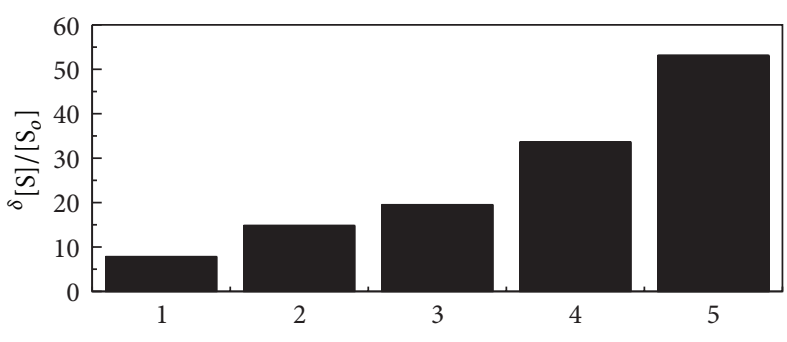

(a)

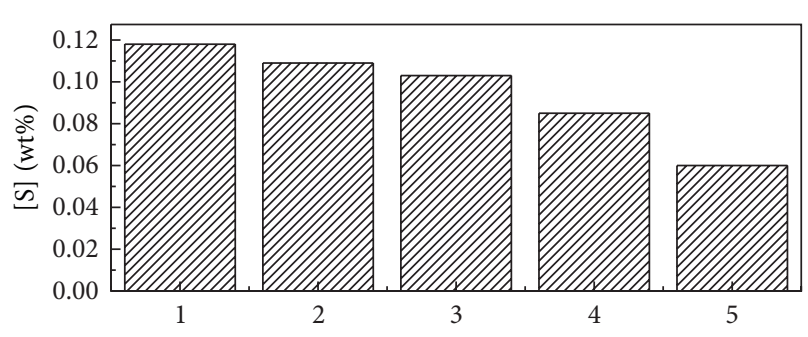

(b)

FIGURE 8: Variation of (a) sulphur content and (b) desulfurization degree of the metal using $250 \mathrm{gm}$ of $\mathrm{CaO}-\mathrm{CaF}_{2}(4: 1)$ in the furnace and adding 250 gm of different types of flux in the mold: (1) $\mathrm{CaO}+\mathrm{CaF}_{2},(2) \mathrm{Na}_{2} \mathrm{CO}_{3}$, (3) $\mathrm{CaO}+\mathrm{CaF}_{2}+\mathrm{Al}_{2} \mathrm{O}_{3},(4) \mathrm{CaO}+\mathrm{CaF}+\mathrm{FeSi}+\mathrm{C}$, and (5) $\mathrm{CaSi}$.

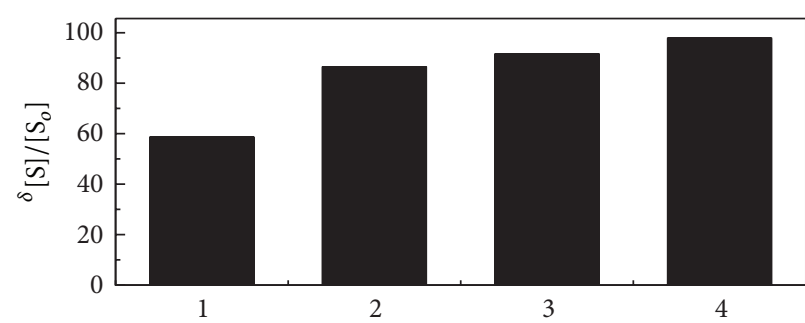

(a)

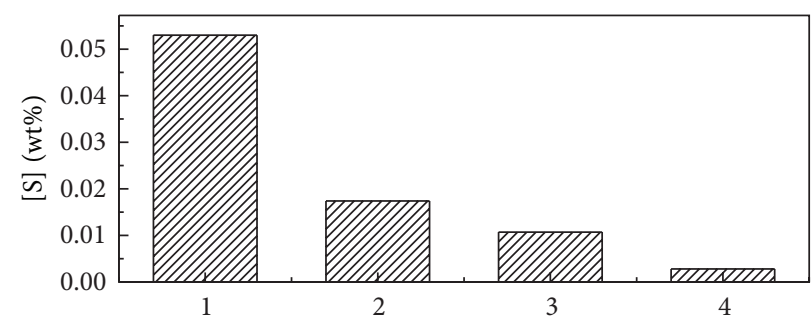

(b)

FIGURE 9: Variation of (a) sulphur content and (b) desulfurization degree of the metal, using $500 \mathrm{gm}$ of $\mathrm{CaO}-\mathrm{CaF}{ }_{2}(4: 1)$ in the furnace with adding 250 gm of different fluxing type in the mold, (1) zero, (2) $\mathrm{CaO}+\mathrm{CaF}_{2}+\mathrm{FeSi}-\mathrm{C}$, and (3) $\mathrm{CaO}+\mathrm{CaF}_{2}(4) \mathrm{CaSi}_{\text {. }}$

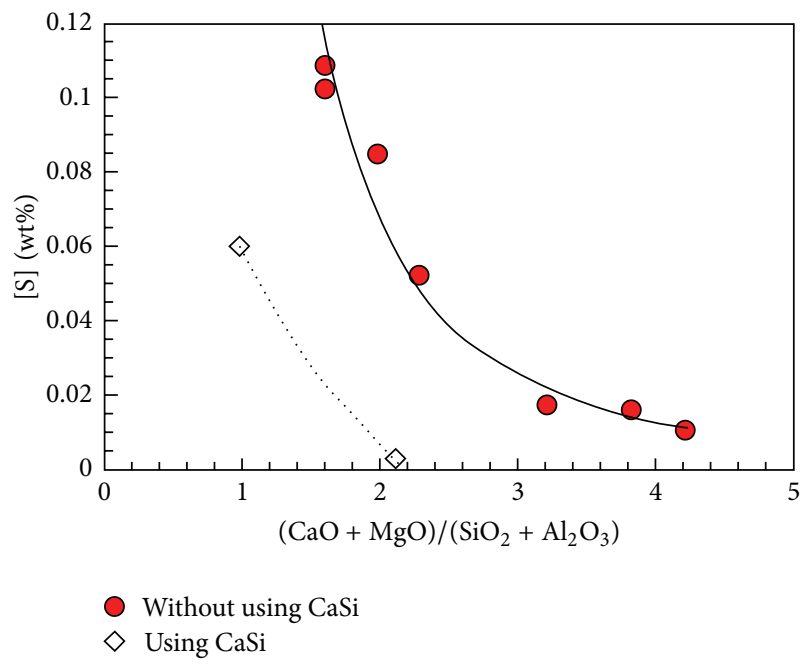

FIGURE 10: Variation of metal sulphur content with slag basicity.

be attributed to the powerful effect of $\mathrm{CaSi}$ as deoxidizing agent results in low activity of oxygen in the melt leading to appropriate conditions for the removal of the sulphur and desulphurization of the metal [13].

\section{Conclusions}

Carbothermic reduction of mill scale waste produced in steelmaking process using two carbonaceous reducing agents (graphite or coke) and different fluxing materials in submerged arc furnace reveal the following conclusions:

(1) The iron recovery increases as the amount of reductant increases up to about 1.5 of stoichiometric molar ratio. Above this amount the increasing of the reductant amount leads to decrease of the iron recovery.

(2) The maximum iron recovery obtained by using coke $(76 \%)$ is lower than by using graphite $(83 \%)$.

(3) The carbon, silicon, and manganese contents of the castable metal increase by increasing the reductant amount. At the same stoichiometric carbon molar ratio, the metal carbon, silicon, and manganese contents when using coke were less than that attained when using graphite.

(4) At different type and amount of the reductant, the metal phosphorous content was low and in the range of the iron and steel making.

(5) Low-sulphur content $(\leq 0.02 \mathrm{wt} \% \mathrm{~S})$ can be attained by using graphite as a reducing agent in amount that equals or exceeds the stoichiometric molar ratio. On the other hand, metal with higher sulphur content was produced when using coke as reducing agent. Producing low-sulphur metal $(\leq 0.02 \mathrm{wt} \% \mathrm{~S})$ necessitates using higher amount of coke that equals or exceeds 1.7 of stoichiometric molar ratio.

(6) The highest degree of desulfurization of $97.8 \%$ and much lower content of sulphur in the castable metal 
$(0.0028 \mathrm{wt} \% \mathrm{~S})$ are obtained by controlling the type and quantity of the flux.

(7) By controlling the type and amount of the reductant and using a suitable fluxing material, mill scale waste produced in steelmaking process can be converted into valuable products such as high purity iron as alternative to Sorelmetal used in ductile iron production, low carbon steel, and free cutting steels.

\section{Conflict of Interests}

The authors declare that there is no conflict of interests regarding the publication of this paper.

\section{References}

[1] L. Camci, S. Aydin, and C. Arslan, "Reduction of iron oxide in solid wastes generated by steelworks," Turkish Journal of Engineering and Environmental Sciences, vol. 26, pp. 37-44, 2002.

[2] T. Umadevi, A. Brahmacharyulu, P. Karthik, P. C. Mahapatra, M. Prabhu, and M. Ranjan, "Recycling of steel plant mill scale via iron ore sintering plant," Ironmaking and Steelmaking, vol. 39, no. 3, pp. 222-227, 2012.

[3] R. Farahat, M. Eissa, G. Megahed, and A. Baraka, "Reduction of mill scale generated by steel processing," Steel Grips, vol. 8, pp. 88-92, 2010.

[4] R. D. Young and D. Norris, "Process for using mill scale in cement clinker production," US Patent, no. 6709510B1, 2004.

[5] O. Benchiheub, S. Mechachti, S. Serrai, and M. G. Khalifa, "Elaboration of iron powder from mill scale," Journal of Materials and Environmental Science, vol. 1, no. 4, pp. 267-276, 2010.

[6] M. I. Martín, F. A. López, and J. M. Torralba, "Production of sponge iron powder by reduction of rolling mill scale," Ironmaking \& Steelmaking, vol. 39, no. 3, pp. 155-162, 2012.

[7] S. Cho and J. Lee, "Metal recovery from stainless steel mill scale by microwave heating," Metals and Materials International, vol. 14, no. 2, pp. 193-196, 2008.

[8] R. C. Gupta, Theory and Laboratory Experiments in Ferrous Metallurgy, Prentice Hall, New Delhi, India, 2010.

[9] K. Mori, H. Wada, and R. D. Pehlke, "Simultaneous desulfurization and dephosphorization reactions of molten iron by soda ash treatment," Metallurgical Transactions B, vol. 16, no. 2, pp. 303-312, 1985.

[10] G. Li, T. Hamano, and F. Tsukihashi, "The effect of $\mathrm{Na}_{2} \mathrm{O}$ and $\mathrm{Al}_{2} \mathrm{O}_{3}$ on dephosphorization of molten steel by high basicity $\mathrm{MgO}$ saturated $\mathrm{CaO}-\mathrm{FeO} \mathrm{x}-\mathrm{SiO}_{2}$ slag," ISIJ International, vol. 45, no. 1, pp. 12-18, 2005.

[11] T. Nagai, Y. Tanaka, and M. Maeda, "Thermodynamic measurement of di-calcium phosphate," Metallurgical and Materials Transactions B, vol. 42, no. 4, pp. 685-691, 2011.

[12] M. M. Eissa, K. A. El-Fawakhry, W. Tayor, H. El-Faramawy, and A. M. Ahmed, "Ferrous oxide activity in $\mathrm{FeO}-\mathrm{TiO}_{2}-\mathrm{CaO}-\mathrm{Al}_{2} \mathrm{O}_{3}$ system," ISIJ International, vol. 36, no. 5, pp. 512-516, 1996.

[13] K. Mineura, I. Takahashi, and K. Tanaka, "Deoxidation and desulfurization of pressurized liquid high nitrogen stainless steels with calcium," ISIJ International, vol. 30, no. 3, pp. 192198, 1990. 

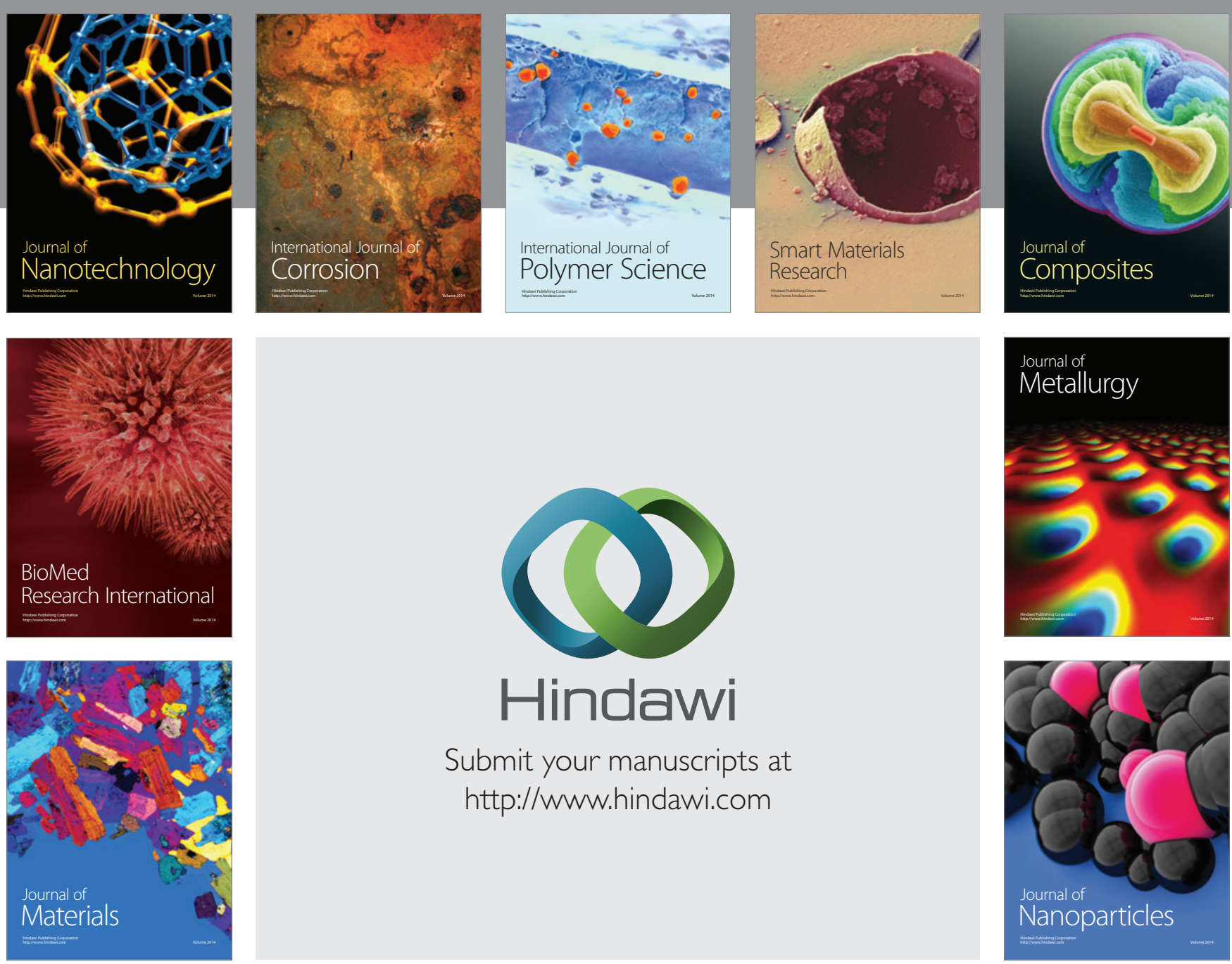

Submit your manuscripts at http://www.hindawi.com
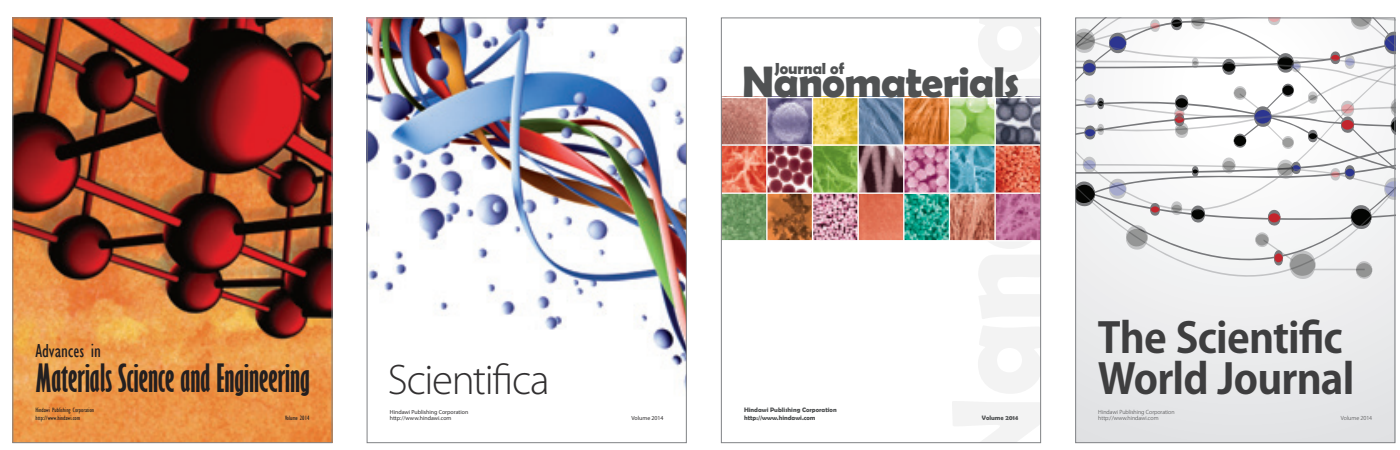

\section{The Scientific World Journal}
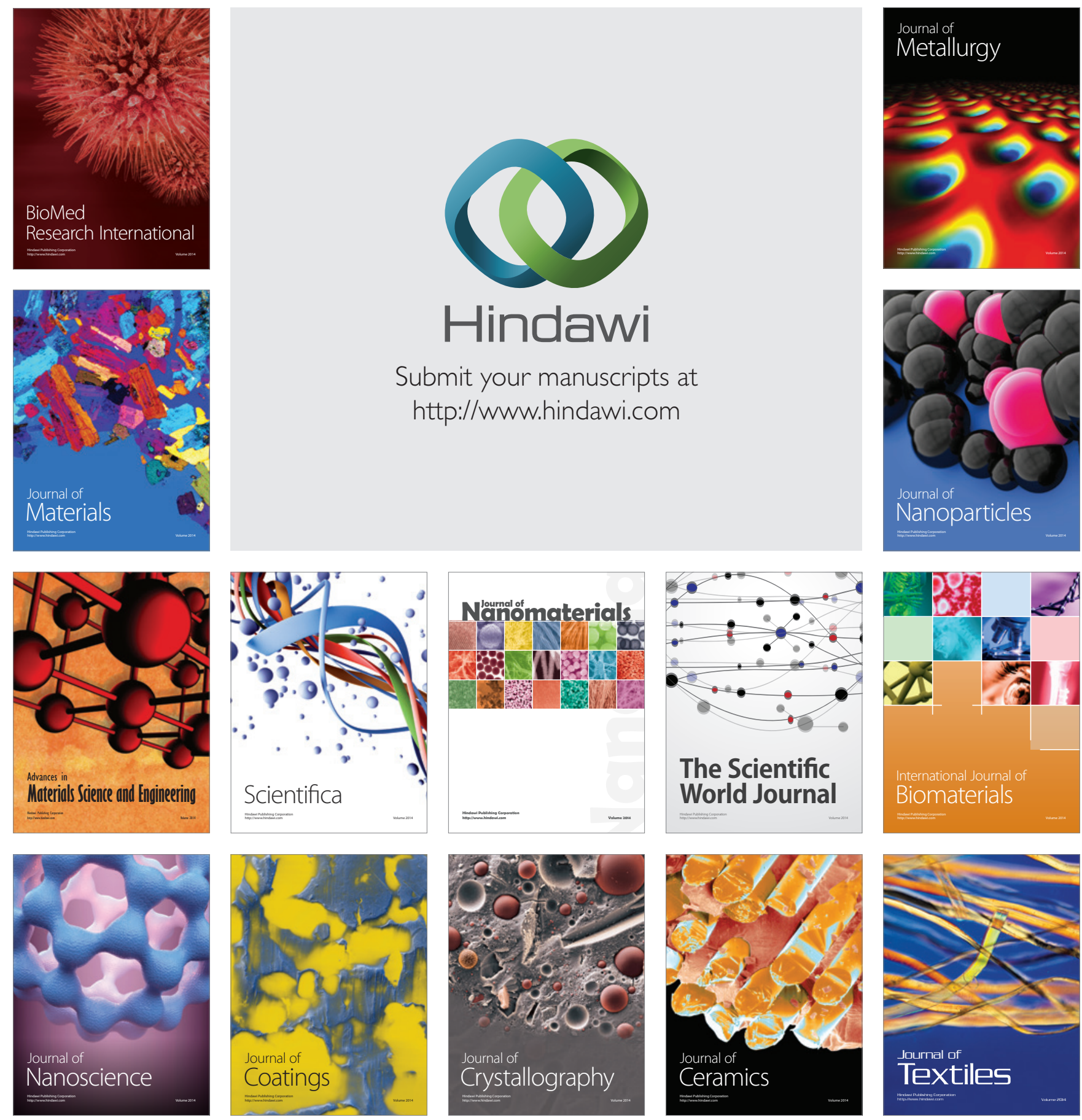